\title{
Pathogenicity to Ornamental Plants of Some Existing Species and New Taxa of Phytophthora from Irrigation Water
}

\author{
Chuanxue Hong, Patricia A. Richardson, and Ping Kong, Virginia Polytechnic Institute and State University, \\ Hampton Roads Agricultural Research and Extension Center, Department of Plant Pathology, Physiology and Weed \\ Science, Virginia Beach, VA 23455
}

\begin{abstract}
Hong, C., Richardson, P. A., and Kong, P. 2008. Pathogenicity to ornamental plants of some existing species and new taxa of Phytophthora from irrigation water. Plant Dis. 92:1201-1207.

Eighteen isolates from 12 species of Phytophthora, including several new taxa, were tested for pathogenicity to six ornamental and four vegetable species. The following three inoculation methods were used depending on infection court targeted: vermiculite culture inoculation for roots, agar block inoculation for fruit, and zoospore inoculation for foliage. All six new taxa $(P$. irrigata, . hydropathica, Dre III, Cil I, Cip-like, and Gon I) are pathogenic to one or more test plants. Specifically, taxon Cil I was identified as a growing threat to horticultural crops, particularly ornamental crops in container production nurseries. The potential host list of $P$. tropicalis was expanded to four new families (Apocynaceae, Asteraceae, Begoniaceae, and Fabaceae) and one additional genus within each of three existing families (Ericaceae, Cucurbitaceae, and Solanaceae). New potential hosts were also identified for other existing species of Phytophthora. The practical implications of these results in crop health management programs for both ornamental and vegetable crops locally, and for development and implementation of agricultural biosecurity programs globally, are discussed.
\end{abstract}

Additional keywords: integrated crop health management

Members of the genus Phytophthora, as implicated in its name, are known as "plant destroyers," and new members have been recently identified at an accelerated pace. Only 59 species of Phytophthora were named over a 120-year period from 1876 to 1996 (6). In contrast, during the past 12 years (from 1996 to 2008), 28 new species were added to the genus (8). In addition, eight new species have been proposed at the National Center for Biotechnology Information (http://www.ncbi.nlm.nih.gov/ blast/Blast.cgi), although they are not yet formally described. This genus as a whole may pose a greater challenge to crop health management locally and plant biosecurity globally than previously thought. There are significant differences in the scope and degree of impact among its members. Some are destructive pathogens of a broad range of plants, whereas others may attack only a few plants or are just weak pathogens $(6,7,10)$. These differences among species highlight the need to understand the pathogenicity of new taxa and the host range of existing species, which will identify major threats from the

Corresponding author: Chuanxue Hong

E-mail: chhong2@vt.edu

Accepted for publication 15 April 2008.

doi:10.1094/PDIS-92-8-1201

(C) 2008 The American Phytopathological Society genus in order to minimize the health risk it poses to agricultural crops and natural forests.

We recently reported nine species of Phytophthora found in irrigation water at ornamental plant nurseries in Virginia through a statewide survey from 1999 to 2006. These include $P$. tropicalis, a taxon recently separated from $P$. capsici and $P$. palmivora complex (1). This species was first documented in the continental United States in 2006 (15). In addition, we have accumulated a large number of isolates that are genetically and morphologically distinct from existing species of Phytophthora. These new taxa include Cil I, Cip-like, Dre I, II, and III, and Gon I. The Cil I taxon was first placed as a subgroup of $P$. citricola according to its morphological resemblance and DNA fingerprint (17). This taxon is listed as a separate, but not completely settled, species in a key to Phytophthora species (10). Further investigations have indicated that isolates of this taxon genetically differ from an authentic isolate (CBS 295.29) of P. citricola from citrus leaf in Japan. This is the only isolate currently available at the CBS that was recovered, identified, and deposited in 1929 by K. Sawada, who named that species. The Cip-like isolates are morphologically similar to $P$. citrophthora, but differ from the latter by growth temperature maximum. The former do not grow at $30^{\circ} \mathrm{C}$, whereas the latter have a temperature maximum between 30 and $35^{\circ} \mathrm{C}$ with an average of $32^{\circ} \mathrm{C}$ (10). Dre I, II, and III are three subgroups of $P$. drechsleri complex. They all are heterothallic, produce nonpapillate sporangia, and grow well at $35^{\circ} \mathrm{C}$. However, these three subgroups differ from true $P$. drechsleri included in the new key (10), and they also differ from one another. Isolates of the three subgroups produce fully plerotic oospores, whereas those of true $P$. drechsleri produce aplerotic to slightly plerotic oospores. They also differ by liberating zoospores immediately after sporangia are formed. In addition, the former have higher optimum and maximum growth temperature than the latter. Within the three subgroups, absence of hyphal swelling and chlamydospores separates Dre I from Dre II (17) as well as Dre III. The Dre III isolates produce smaller sporangia but larger chlamydospores than the Dre II. The Dre I and II are provisionally named Phytophthora irrigata and Phytophthora hydropathica, respectively (12). The Gon I isolates morphologically resemble but genetically are distinct from $P$. gonapodyides. These existing species and new taxa were frequently isolated from irrigation systems in Virginia.

A pathogenicity test is the first step to assess the economic and ecological significance of Phytophthora species present in irrigation systems (13). Water isolates of $P$. cactorum, $P$. citrophthora, and $P$. nicotianae from a nursery in southwestern Virginia were pathogenic to Salvia officialis; however, the other frequently isolated species from the same nursery were not (3). The present study expanded that research to include some existing and new taxa of irrigation water origin and test them with a broad range of hosts. The primary goal of this study was to provide a basis for assessing the health risk to horticultural crops of individual species of Phytophthora commonly isolated from irrigation water in Virginia.

\section{MATERIALS AND METHODS}

Test plants. A large selection of plants was used in the attempt to determine the pathogenicity associated with these new taxa from aquatic environments. Each plant was selected based on its susceptibility to a large number of known Phytophthora species $(6,7,10)$. These plants included six ornamentals and four vegetables. Their names and respective cultivars 
used in the tests with vermiculite culture are listed in Table 1. Additional cultivars were used for four vegetable species in some tests, and their names will be provided below in the respective sections.

Isolates. A total of 18 isolates belonging to 12 species of Phytophthora including six new taxa (Table 2) were tested in this study. Thirteen originated from irrigation water of ornamental plant nurseries, while five isolated from diseased plants were included for comparison in some tests. Cultures of 4E4 (MYA-4458) and 5D1 (MYA-4460) have been deposited at the

Table 1. Species and cultivars of test plants and type of inoculum used in individual inoculation tests performed in the present study ${ }^{\mathrm{v}}$

\begin{tabular}{|c|c|c|c|c|c|}
\hline \multirow[b]{2}{*}{ Test plant species } & \multirow[b]{2}{*}{ Cultivar ${ }^{w}$} & \multicolumn{2}{|c|}{ Infested potting mix ${ }^{x}$} & \multirow{2}{*}{$\begin{array}{l}\text { Inoculation } \\
\text { of fruit }\end{array}$} & \multirow{2}{*}{$\begin{array}{c}\text { Inoculation } \\
\text { of foliage }^{\mathrm{z}}\end{array}$} \\
\hline & & Seeded & Transplanted & & \\
\hline \multicolumn{6}{|l|}{ Ornamental } \\
\hline Begonia sp. & Nonstop & + & + & - & - \\
\hline Catharanthus roseus & Little Bright Eye & + & + & - & - \\
\hline Gerbera jamesonii & Aurantiac mix & + & + & - & - \\
\hline Lupinus albus & Russell mixed & + & + & - & - \\
\hline $\begin{array}{l}\text { Rhododendron } \times \\
\text { Kurume }\end{array}$ & Hershey's Red & - & + & - & - \\
\hline $\begin{array}{l}\text { Senecio bicolor } \\
\quad \text { subsp. cineraria }\end{array}$ & Silver Dust & + & + & - & - \\
\hline \multicolumn{6}{|l|}{ Vegetable } \\
\hline Cарsicum аппиит & California Wonder & + & + & + & + \\
\hline Cucumis sativus & Orient Express & + & + & - & - \\
\hline $\begin{array}{l}\text { Lycopersicon } \\
\text { esculentum }\end{array}$ & Homestead & + & + & + & - \\
\hline Solanum melongena & Black Bell & + & + & + & - \\
\hline Type of inoculum used & & \multicolumn{2}{|c|}{ Vermiculite culture } & Agar block & $\begin{array}{l}\text { Zoospore } \\
\text { suspension }\end{array}$ \\
\hline
\end{tabular}

$\mathrm{v}+=$ test performed, and $-=$ test not performed with a specific plant.

${ }^{\text {w }}$ These cultivars were used in the tests by seeding or transplanting into infested potting mixes.

${ }^{x}$ Test plants were seeded and/or transplanted into infested potting mix. African daisy (Aurantiac mix) and cucumber (Orient Express) were tested separately from the remaining test plants.

${ }^{y}$ Fruits were purchased from a local grocery store, cultivars unknown.

${ }^{\mathrm{z}}$ Eight different cultivars were used in this test. All seedlings free of Phytophthora species were donated by a local nursery.

Table 2. Summary of Phytophthora isolates evaluated in individual inoculation tests ${ }^{v}$

\begin{tabular}{|c|c|c|c|c|c|c|}
\hline \multirow[b]{2}{*}{ Taxon code ch $^{\mathrm{w}}$} & \multirow[b]{2}{*}{ Species $^{x}$} & \multirow[b]{2}{*}{ Isolate } & \multicolumn{2}{|c|}{ Infested potting mix ${ }^{y}$} & \multirow[b]{2}{*}{$\begin{array}{c}\text { Fruit } \\
\text { inoculation }\end{array}$} & \multirow[b]{2}{*}{$\begin{array}{c}\text { Foliage } \\
\text { inoculation }\end{array}$} \\
\hline & & & $\begin{array}{l}\text { African daisy } \\
\text { \& cucumber }\end{array}$ & $\begin{array}{c}\text { Other test } \\
\text { plants }\end{array}$ & & \\
\hline \multicolumn{7}{|c|}{ Isolates originating in irrigation water } \\
\hline Cil I & TBN & 16A8 & - & + & + & - \\
\hline Cil I & TBN & $11 C 9$ & + & - & - & - \\
\hline Cip & P. citrophthora & 16A7 & + & - & - & - \\
\hline Cip-like & TBN & 4B3 & + & - & - & - \\
\hline Irr (Dre I) & P. irrigata & 4E4 & + & + & + & - \\
\hline Hyd (Dre II) & P. hydropathica & 5D1 & + & + & + & - \\
\hline Dre III & TBN & $6 \mathrm{C} 2$ & + & + & + & - \\
\hline Gon I & TBN & 16B5 & + & + & + & - \\
\hline Meg & P. megasperma & $9 \mathrm{~J} 2$ & - & + & + & - \\
\hline Pal & P. palmivora & 7A9 & - & + & + & - \\
\hline Tro & P. tropicalis & 7G9 & - & + & + & + \\
\hline Tro & P. tropicalis & $7 \mathrm{H} 3$ & + & - & - & + \\
\hline Tro & P. tropicalis & $7 \mathrm{~J} 3$ & - & - & - & + \\
\hline \multicolumn{7}{|c|}{ Isolates from diseased plants ${ }^{\mathrm{z}}$} \\
\hline Cap & P. capsici & $22 \mathrm{~F} 4$ & - & - & - & + \\
\hline Cap & P. capsici & $22 \mathrm{H} 3$ & - & - & - & + \\
\hline Cap & P. capsici & $22 \mathrm{H} 4$ & - & - & - & + \\
\hline $\mathrm{Nic}$ & P. nicotianae & 1B11 & - & + & + & - \\
\hline Tro & P. tropicalis & $22 \mathrm{H} 5$ & - & - & - & + \\
\hline
\end{tabular}

$\mathrm{v}+=$ test performed, and $-=$ test not performed for a specific species or isolate of Phytophthora.

${ }^{w}$ Name of PCR-SSCP pattern: Gon I = a subgroup of $P$. gonapodyides, $\mathrm{Cil} \mathrm{I}=$ a subgroup of $P$. citricola, Cip-like $=$ a subgroup of $P$. citrophthora complex, Dre I, II, and III $=$ three subgroups of $P$. drechsleri complex. Taxa Dre I and II were recently named Phytophthora irrigata and Phytophthora hydropathica, respectively.

$\times \mathrm{TBN}=$ to be named.

y 'Aurantiac mix' African daisy and 'Orient Express' cucumber were used in the first test, and the remaining plant species were used in the second test.

${ }^{\mathrm{z}}$ Name of host plants: Catharanthus roseus for 1B11, Capsicum annuum for 22F4, Cucumis sativus for $22 \mathrm{H} 3$, and Vanilla sp. for $22 \mathrm{H} 5$, respectively. Host of $22 \mathrm{H} 4$ is unknown.
American Type Culture Collection under the provisional names of $P$. irrigata and $P$. hydropathica (12). The sequence accession numbers at the GenBank are EU595771 and EU583793 for 4E4 and 5D1, respectively. Per the instructions from these public repositories, cultures and sequences of other new taxa will be deposited after they are described, and they will be deposited under the same isolate identities as listed in Table 2.

Vermiculite culture inoculation. Thirteen isolates from 11 species were evaluated through vermiculite inoculation (Table 2) in two separate tests. The first test used African daisy and cucumber and was conducted in late spring of 2002. The second test used annual vinca, azalea, begonia, dusty miller, eggplant, lupine, pepper, and tomato, and it was done in early fall of the same year. Vermiculite cultures were prepared as described previously $(16,24)$ and mixed with the potting mix Metro Mix 360 (Scotts-Sierra Horticultural Products Company, Marysville, OH, USA) at a rate of $2 \%$ ( $\mathrm{vol} / \mathrm{vol})$. Each test consisted of two separate subtests: (i) seeding, and (ii) transplanting test plants into infested potting mix in multicell plastic flats. Each subtest included (i) plant controls that were seeded or transplanted into potting mix in the absence of Phytophthora species, and (ii) potting mix controls that were infested artificially but not used for planting to determine the survival of individual Phytophthora species in the absence of a plant. Each test included three to four replicates with 12 to 24 seeds or seedlings per plant species per replicate and was repeated once.

The following measurements were included in data sets: counts of (i) seedlings, (ii) diseased plants, (iii) infected plants without aboveground symptoms, and (iv) infestation levels of potting mix at the beginning and termination of each test. Seedlings were counted at 7 and 14 days after seeding. Thereafter, plants were inspected regularly for disease symptoms. A plant showing damping-off symptoms was recorded as "diseased". This was further confirmed through plating symptomatic tissues on PARP-V8 agar (9) after surface sterilization with $0.6 \%$ sodium hypochlorite for $30 \mathrm{~s}$. At the termination of each test (about 35 to 70 days after seeding or transplanting), roots of remaining plants were also plated. Plants from which Phytophthora isolates were recovered were recorded as "infected". In addition, $1 \mathrm{~g}$ of potting mix was mixed with $5 \mathrm{ml}$ of sterile distilled water (SDW) and mixed by vortexing for $2 \mathrm{~min}$; then $100 \mu \mathrm{l}$ of mixture was plated undiluted, at $10 \times$ or $100 \times$ dilution in $10-\mathrm{cm}$ petri dishes with PARP-V8 agar. Resultant colony-forming units (CFU) were counted daily after plating, and cumulative $\mathrm{CFU} / \mathrm{g}$ potting mix was used to measure the infestation level. Both tests were repeated once. 
Seeding and transplanting test plants into artificially infested potting mix produced similar results in both tests. Only data from seeding will be presented for the first test with African daisy and cucumber, and those from transplanting will be presented for the second test with the remaining plant species.

Agar block inoculation. Nine species of Phytophthora with one isolate each were assessed on eggplant, pepper, and tomato (Table 2). Fresh fruits of unknown cultivars were purchased from a local farmers market. They were prepared by surface sterilization with $70 \%$ ethanol, rinsing with SDW, punching a hole in each with a sterile cork borer, and then placed in moist containers before inoculation. Agar blocks ( $4 \mathrm{~mm}$ diameter) were taken from the advancing edge of 5-day-old cultures on clarified V8 agar and were placed in the premade holes (28). Uninoculated V8 agar blocks were used as controls. Inoculated fruits were incubated at room temperature for 7 days and were checked for rotting symptoms daily. Diameter of the rotting area of each fruit was measured 48 and 72 $\mathrm{h}$ after inoculation. Actual rotting area, excluding the hole, was computed, and only the measurements taken at $72 \mathrm{~h}$ are presented. The test, including 15 fruits of each vegetable in triplicate, was repeated once.

Zoospore inoculation. Three isolates of $P$. tropicalis from irrigation water were evaluated by zoospore inoculation (Table $2)$. One isolate (22H5) of the same species and three isolates of $P$. capsici from diseased plants were included for comparison. Zoospores were produced as described

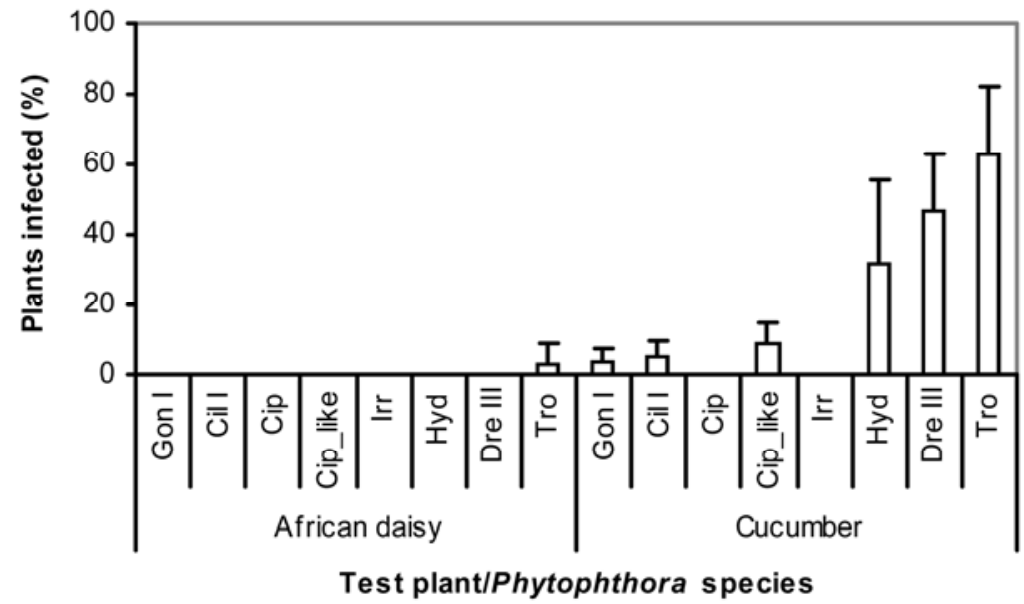

Fig. 1. Infection of roots by individual species of Phytophthora 1 month after test plants were seeded into artificially infested potting mix: Gon $\mathrm{I}=$ a subgroup of $P$. gonapodyides, Cil $\mathrm{I}=$ a subgroup of $P$. citricola complex, Cip $=P$. citrophthora, Cip_like $=P$. citrophthora-like species having low growth temperature maximum, Irr $=P$. irrigata, $\mathrm{Hyd}=P$. hydropathica, Dre III $=$ a subgroup of $P$. drechsleri complex, and Tro $=P$. tropicalis. Each column and bar represents a mean and standard deviation of Phytophthora recoveries from four replicates with 23 plants each. previously (14), and the resultant suspension was diluted with SDW to 2,000 zoospores/ml for inoculation.

Eight cultivars of sweet pepper were used as test plants. These cultivars were the following: (i) Big Bertha, (ii) Blushing Beauty, (iii) California Wonder, (iv) Keystone Giant, (v) Pimiento, (vi) Purple Blue, (vii) Red Bell, and (viii) Yellow Belle. Seedling plugs were donated by a local greenhouse producer with no history of Phytophthora disease on peppers. One plug from each cultivar was placed in a multicell plastic flat. They were inoculated by spraying $2 \mathrm{ml}$ of inoculum at 2,000 zoospores/ml per seedling using a hand mister. Inoculated plants were covered with a plastic sheet to keep moist overnight (15 h) and facilitate infection, then maintained under greenhouse conditions for 7 days. Disease development was rated on the following 0 to 3 scale: asymptomatic (0), localized necrosis (1), foliage blight (2), and plant wilted (3). The test included four replicates and was repeated once.

Experiment design and data analyses. Treatments within a test were arranged in a complete block design. Analysis of variance (ANOVA) was performed to determine the significance of differences in disease incidence and severity among treatments within each test using the SAS Systems for Window v8 (SAS Institute, Cary, NC).

\section{RESULTS}

Vermiculite culture inoculation. The first test. Almost all 24 cucumber seeds germinated, whereas African daisy did not germinate as well, resulting in an average of 23 versus 7 seedlings in the noninfested controls. Among the eight species of Phytophthora assessed, only $P$. hydropathica and the Dre III taxon reduced the number of seedlings, and this reduction was lim-

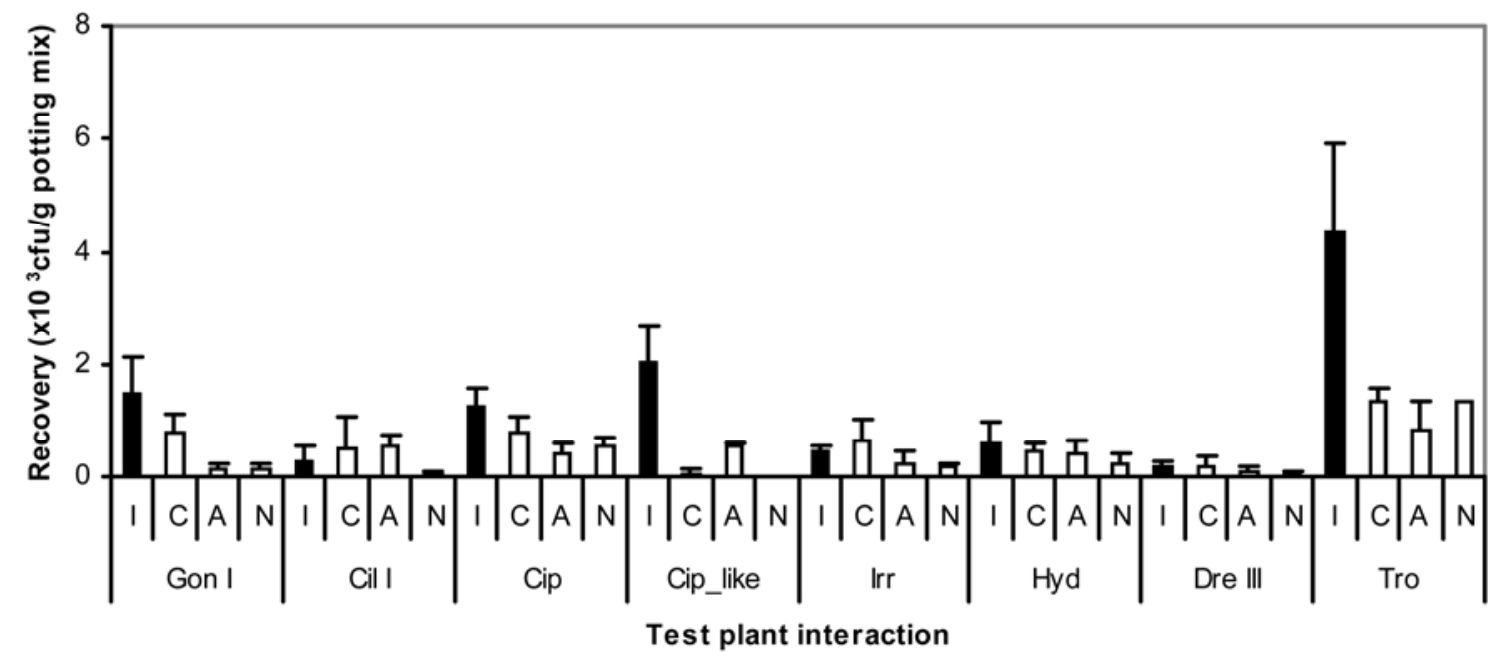

Fig. 2. Changes in population of eight species of Phytophthora in potting mixes over a 1-month period from incorporating vermiculite culture (I) to the termination of test: $\mathrm{N}=$ absence of a test plant, $\mathrm{C}$ and $\mathrm{A}=$ presence of cucumber and African daisy, respectively; Gon $\mathrm{I}=\mathrm{a}$ subgroup of $P$. gonapodyides, Cil $\mathrm{I}=$ a subgroup of $P$. citricola complex, Cip $=P$. citrophthora, Cip_like $=P$. citrophthora -like species having low growth temperature maximum, Irr $=P$. irrigata, Hyd $=P$. hydropathica, Dre III $=$ a subgroup of $P$. drechsleri complex, and Tro $=P$. tropicalis. Each column and bar represents a mean and standard deviation of Phytophthora recoveries from four replicates. 
ited to cucumber only. The seedling reduction was $61 \%$ by P. hydropathica and $27 \%$ by Dre III. No seedling reduction was observed in African daisy by any species of Phytophthora tested.

Damping-off symptoms were observed in one treatment where cucumber was seeded in potting mix infested with $P$. tropicalis. The disease incidence was $18 \%$. No aboveground disease symptoms were observed in any other treatments (Phytophthora species and test plant combinations).

Phytophthora species were not isolated from any roots of both test plants in noninfested controls. Root infection was detected in cucumber seedlings removed from infested potting mixes with all species of Phytophthora except for $P$. citrophthora and P. irrigata (Fig. 1). As expected, the greatest rate of root infection was caused by $P$. tropicalis, followed by $P$. hydropathica and the Dre III taxon. Root infection was detected in African daisy seeded in P. tropicalis-infested potting mix but not any other species of Phytophthora tested.

All species of Phytophthora assessed in this study tended to decline over time after incorporating vermiculite culture into the potting mix regardless of the presence of test plants (Fig. 2). This is the most obvious for $P$. tropicalis, $P$. citrophthora, and the Cip-like and Gon I isolates. For example, the rate of recovery was $4,350 \mathrm{CFU} / \mathrm{g}$ potting mix for $P$. tropicalis at the beginning of the test. This rate dropped to 850 and 1,350 CFU/g potting mix, respectively, in the presence of African daisy and cucumber as well as in the absence of any plant (Fig. 2). P. irrigata slightly increased over time during the first run (Fig. 2), but it also declined in the second run.

The second test. None of the 12 control seedlings per test species transplanted in noninfested potting mix developed any disease symptom, nor were Phytophthora species isolated. However, wilting symptoms as a result of root rotting were observed in up to 7 out of the 12 plants, depending on the test plant and Phytophthora species tested (Table 3). Among the eight species of Phytophthora, P. tropicalis and $P$. nicotianae attacked four of the eight test plants. Both species were isolated from roots of seven test plants. Next to these two species is the Cil I taxon, which was isolated from five test plants. Among the eight test plants, azalea had the most diversity of Phytophthora species (all tested).

All species of Phytophthora appeared to decline over time in the potting mixes with only one exception. This decline is most apparent in the absence of test plant as illustrated by the Gon I taxon (Fig. 3). Test plants appeared to have slowed down this declining process. The only exception is the Cil I taxon (Fig. 3). Population of this species increased over time, especially in the presence of test plants.

Agar block inoculation. $P$. tropicalis was the most aggressive species to all three hosts, followed by $P$. nicotianae and the Dre III taxon for eggplant and pepper, and the Cil I taxon and P. palmivora for tomato among the nine species assessed (Fig. 4). Tomato was the most susceptible host to all nine species of Phytophthora among the three hosts used.

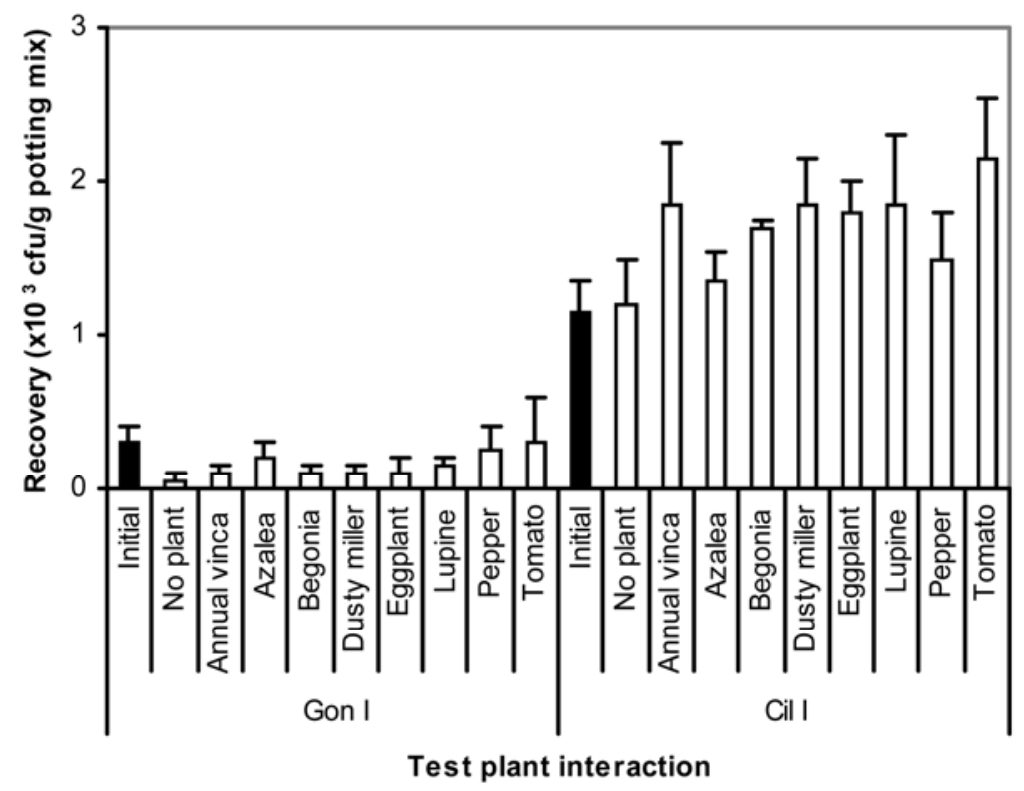

Fig. 3. Changes in population of Phytophthora gonapodyides (Gon I) and P. citricola (Cil I) in potting mixes over a 70-day period from incorporating vermiculite culture ("Initial") to the termination of test in the absence and presence of a specific test plant. Each column and bar represents a mean and standard deviation of Phytophthora recoveries from three replicates.

Table 3. Infection of test plants by individual species of Phytophthora after being transplanted into artificially infested potting mix ${ }^{\mathrm{y}}$

\begin{tabular}{|c|c|c|c|c|c|c|c|c|c|}
\hline Plants & Pathogen $^{\mathrm{z}}$ & Annual vinca & Azalea & Begonia & Dusty miller & Eggplant & Lupine & Pepper & Tomato \\
\hline \multirow[t]{9}{*}{ Diseased } & Gon I & 0 & 3 & 0 & 0 & 2 & 0 & 0 & 0 \\
\hline & Cil I & 0 & 3 & 0 & 0 & 0 & 1 & 0 & 0 \\
\hline & P. irrigata $(=$ Dre I) & 0 & 4 & 0 & 0 & 0 & 0 & 0 & 0 \\
\hline & $\begin{array}{l}\text { P. hydropathica } \\
\text { (=Hyd, Dre II) }\end{array}$ & 0 & 4 & 0 & 0 & 0 & 0 & 0 & 0 \\
\hline & Dre III & 0 & 7 & 0 & 0 & 0 & 0 & 0 & 0 \\
\hline & P. megasperma & 0 & 0 & 0 & 0 & 0 & 1 & 0 & 0 \\
\hline & P. nicotianae & 2 & - & 0 & 0 & 7 & 1 & 0 & 3 \\
\hline & P. palmivora & 0 & 4 & 0 & 0 & 1 & 0 & 0 & 0 \\
\hline & P. tropicalis & 7 & 4 & 0 & 2 & 2 & 0 & 0 & 0 \\
\hline \multirow[t]{9}{*}{ Infected } & Gon I & 0 & 12 & 0 & 0 & 0 & 0 & 0 & 0 \\
\hline & Cil I & 0 & 10 & 7 & 0 & 2 & 0 & 4 & 2 \\
\hline & P. irrigata $(=$ Dre I) & 0 & 0 & 0 & 0 & 0 & 0 & 4 & 1 \\
\hline & P. hydropathica (=Dre II) & 0 & 12 & 0 & 2 & 0 & 0 & 2 & 1 \\
\hline & Dre III & 0 & 0 & 1 & 0 & 0 & 0 & 4 & 0 \\
\hline & P. megasperma & 0 & 5 & 0 & 0 & 0 & 0 & 2 & 0 \\
\hline & P. nicotianae & 1 & - & 3 & 2 & 4 & 0 & 9 & 4 \\
\hline & P. palmivora & 0 & 10 & 1 & 0 & 0 & 0 & 4 & 2 \\
\hline & P. tropicalis & 6 & 10 & 1 & 1 & 0 & 1 & 7 & 9 \\
\hline
\end{tabular}

y Number of plants diseased or infected out of 12 per species in three replicates (4 each). Phytophthora species was not recovered from any plants in noninfested controls.

z Phytophthora species assessed: Gon I = a subgroup of $P$. gonapodyides, Cil $\mathrm{I}=$ a subgroup of $P$. citricola, Dre III = a subgroup of $P$. drechsleri complex. 
Zoospore inoculation. None of the four isolates of $P$. tropicalis incited disease symptoms on any seedlings of the eight cultivars of sweet pepper (Fig. 5). Two of the three isolates of $P$. capsici caused severe foliage blight on most cultivars. These two isolates belong to $\mathrm{A}^{1}(22 \mathrm{H} 3)$ and $\mathrm{A}^{2}$ (22F4) mating types, respectively. The isolate $22 \mathrm{H} 4$ also is an $\mathrm{A}^{1}$ mating type but did not cause any disease symptoms on any seedlings of all eight cultivars.

\section{DISCUSSION}

Understanding the pathogenicity of new taxa and the host range of existing species of Phytophthora is crucial to assess and mitigate disease risk as illustrated by $P$. ramorum, the sudden oak death pathogen $(11,20,23,26,27)$. The pathogenicity to six ornamental and four vegetable species of 13 water isolates belonging to 10 Phytophthora species was determined. All six new taxa are pathogenic to one or more test plants used in this study, and the existing species pose greater health risk to a broader range of plants than previously assessed. Specifically, this study identified the Cil I taxon as a growing threat to ornamental crops in container production nurseries. These results again underscore the epidemiological and economic significance of irrigation water as a source of inoculum for Phytophthora disease epidemics (13). They have several practical implications for plant health management in the horticultural industries as well as natural forests.

This study identified new health risks to ornamental crops and provided examples for further investigation into the host ranges of individual Phytophthora species. Specifically, azalea is susceptible to $P$. hydropathica, $P$. irrigata, and other new taxa (Table 3). Most plants are prone to attack by more species of Phytophthora

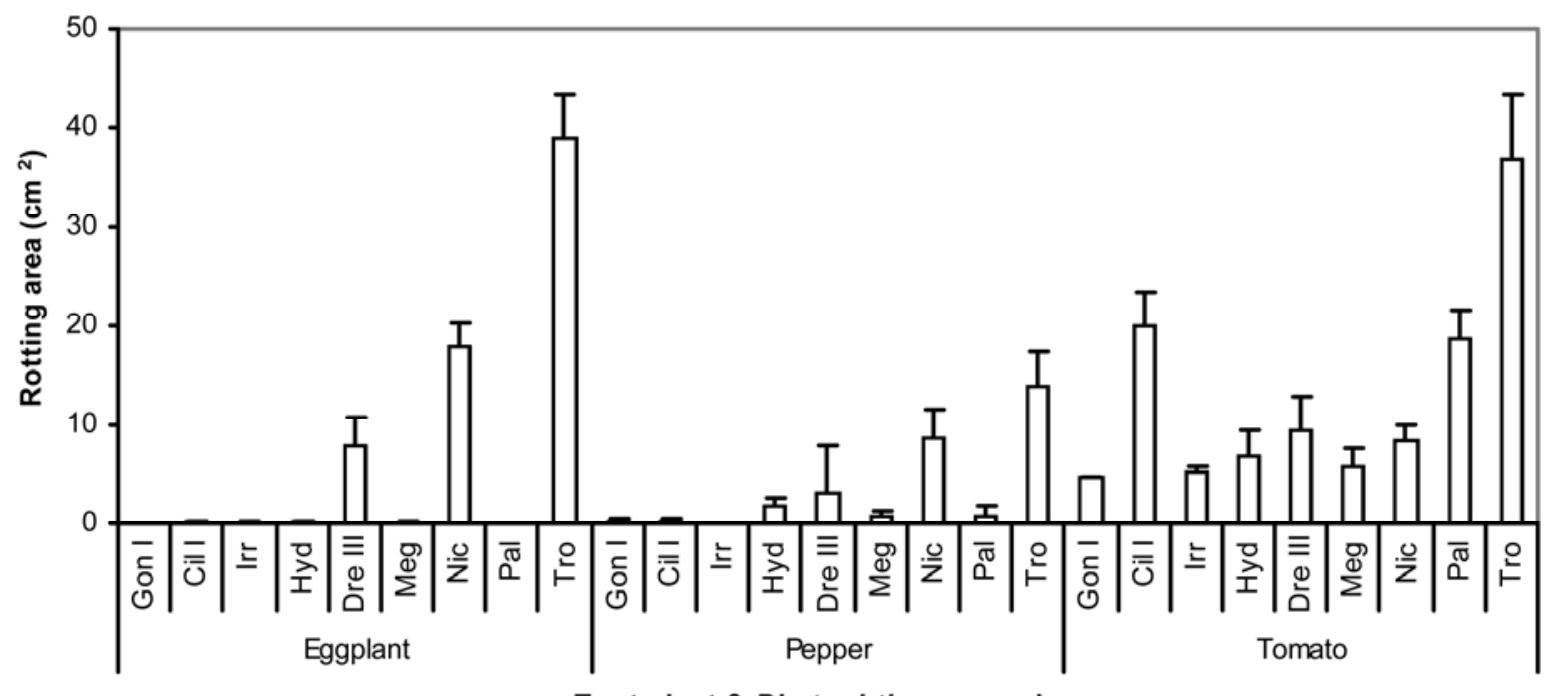

Fig. 4. Disease development on three vegetables $72 \mathrm{~h}$ after inoculation with a mycelium block into a 5-mm wound on fruit surface. Each column and bar represents a rotting area mean and standard deviation of three replicates with five fruit each. Gon I = a subgroup of Phytophthora gonapodyides, Cil I $=$ a subgroup of $P$. citricola, $\mathrm{Irr}=P$. irrigata, $\mathrm{Hyd}=P$. hydropathica, Dre III $=$ a subgroup of $P$. drechsleri, $\mathrm{Meg}=P$. megasperma, $\mathrm{Nic}=P$. nicotianae, Pal $=P$. palmivora, and Tro $=P$. tropicalis .

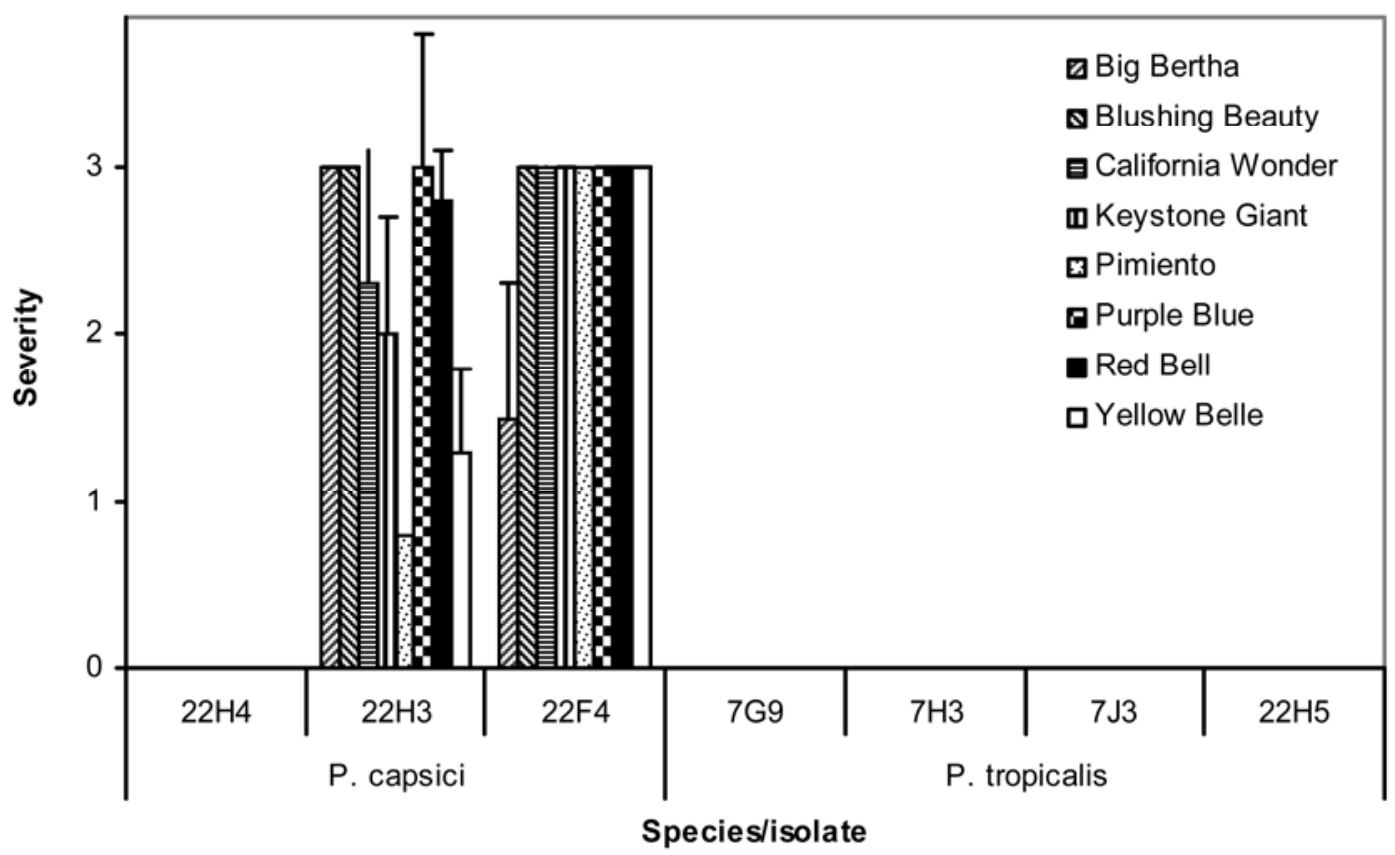

Fig. 5. Immunity of sweet pepper seedlings of eight cultivars to zoospore infection by four isolates of Phytophthora tropicalis in comparison with three isolates of $P$. capsici. 
than currently documented $(6,7,10)$. As noted by Baker and Linderman (2) and Daughtrey and Benson (5), an individual production facility may grow hundreds of species and varieties of plants, and such diversity is unique to the ornamental crop production industry. The selection of test plants used in the present study remains minimal compared to the diversity of plant species grown in commercial nurseries. Thus, the results of the present study should be considered only as examples for further investigations into the host ranges of individual Phytophthora species. Using these data as a guide, $P$. hydropathica has already been isolated from diseased leaves and shoots of Rhododendron sp. and from the stem base of Pieris japonica, and the Dre III taxon from the stem base of Rhododendron sp. in the past 3 years (C. Hong, unpublished data). These isolations not only confirmed the results of the present study, but also identified additional hosts for these two taxa.

These results have use for developing disease prevention programs in the green industry. Ornamental crops are among those most vulnerable to disease problems because of the production systems and product nature; and prevention is crucial to successful plant health management programs. First, recapturing of surface water for irrigation and reuse of plastic containers and green wastes are common practices at production nurseries and greenhouses (13). These practices all potentially recycle inoculum and increase disease pressure. Second, the ornamental plant industry produces a live commodity that needs to survive shipment and retail processes, then becomes established and continues to grow in the landscape. Thus, ornamental plants face additional health risks over field crops. Too often plants are infected, but look healthy under intense chemical protection programs at production facilities. These plants are lost after they leave production beds, either during transportation, retail, or at their final destinations. Two major factors may contribute to these plant losses. Most landscapers, ground maintenance personnel, and homeowners do not perceive the need for chemical protection when they purchase healthy-looking plants. When chemical protection discontinues, pathogens reproduce rapidly. On the other hand, plants experience enormous environmental stresses during shipment, retail, and establishment in the landscape. Disease explodes when stressed plants meet mass inoculum. Thus, preventing a pathogen from entering the crop systems is the first and most important line of defense for the health of ornamental crops (5). The results of the present study may help prevent and deter disease progress by avoiding rotation of host plants within the same production beds and placement of host plant species adjacent to each other. They can also help identify what pathogens to monitor and develop integrated disease management programs to mitigate Phytophthora disease risk.

The present study also demonstrated a potential linkage between ornamental diseases and vegetable crop health. Several existing species of Phytophthora currently known to be pathogenic to only ornamental crops and new taxa from nursery irrigation water could potentially attack the four vegetable species used in this study. For example, $P$. cactorum, $P$. capsici, and $P$. drechsleri are known to attack cucumber (7). The present study demonstrated that $P$. tropicalis and five new taxa also may attack this plant (Fig. 3). Similarly, P. capsici and $P$. nicotianae are reported to attack pepper (7). The results of this study indicate that seven other species $(P$. hydropathica, $P$. irrigata, $P$. megasperma, $P$. palmivora, $P$. tropicalis, and two taxa to be named) also may attack the same plants (Table 3). Tomato is reportedly prone to attack by eight Phytophthora species, including $P$. nicotianae and $P$. palmivora (7). This study added four more species (Table 3) to its already large variety of Phytophthora pathogens. It is likely that some of these additions are those currently listed as unidentified species of Phytophthora under each of the four vegetable plants (7). It must be noted that the majority of these pathogenicity tests were performed in containers with potting mix (soilless medium), which mimics ornamental production in greenhouses and open fields. A similar cultural system is used for production of cucumber, eggplant, pepper, and tomato in greenhouses but not in the fields. Thus, applicability of the pathogenicity data obtained in this study to open field production of these four vegetables is yet to be verified. Nevertheless, this study indicated that a wider range of Phytophthora species may attack both vegetable and ornamental crops. This linkage implies that these pathogens may be spread from ornamental plant nurseries to vegetable farms through irrigation water and vice versa if they use the same water resources. It again highlights the importance of developing and implementing integrated disease management programs for multiple crops and forests (23).

$P$. tropicalis may have a much broader host range of plants than currently documented. As of 22 March 2008, this pathogen was reported to attack 17 species belonging to 16 genera in 14 families (8). This study expanded its potential host list to include the following four new families: Apocynaceae (C. roseus), Asteraceae ( $G$. jamesonii and $S$. bicolor subsp. cineraria), Begoniaceae (Begonia sp.), and Fabaceae (L. albus). Rhododendron catawbiense (Ericaceae) and Sechium edule (Cucurbitaceae) are known hosts of $P$. tropicalis $(1,15)$. Thus, it was not unexpected that azalea and cucumber developed root rot and damping-off in the present study, as they belong to the same families. Likewise, it was expected that tomatoes and peppers developed severe fruit rot (Fig. 4) and root infection (Table 3), as they are in the same family as eggplant. These results expanded three existing host families for $P$. tropicalis: two genera (Capsicum and Lycopersicon) in Solanaceae and one each in $\mathrm{Cu}$ curbitaceae (Cucumis) and Ericaceae (Azalea). Zoospore inoculation did not cause foliage blight of pepper by $P$. tropicalis, which is in agreement with the observations of Aragaki and Uchida (1). However, substantial root infection (vermiculite culture inoculation) and fruit rot (agar block inoculation) were observed. These results indicate that immunity of pepper may not be as reliable a taxonomic character for this species as anticipated. Use of morphological characters and DNA fingerprints $(6,10,17,18)$, as well as sequence analysis $(4,19,21)$, is recommended to correctly identify this species.

$P$. tropicalis may also pose a greater health risk to agricultural crops than previously revealed. This pathogen was isolated from eggplant (1). This study demonstrated that it may attack this species throughout growing seasons (seedling and mature plant), resulting in damping-off and fruit rot. Isolation of $P$. tropicalis from irrigation water and natural soil (15) is an indication of its aquatic and soil inhabitant nature. Irrigation water is not only an important source of inoculum, but also an efficient means of pathogen dissemination from a single point of infection to an entire farm and from a single farm to all other farms that share the same water resources (13). Pathogen monitoring and water decontamination are crucial to successful disease management programs for ornamental and vegetable crops susceptible to attack by $P$. tropicalis.

The Cil I taxon presents significant health risks to a range of plants. Specifically, this species was reisolated from roots in six of the eight test plants (Table $3)$. The same species was isolated previously from diseased rhododendron plants in West Virginia (10) and Ohio (17), as well as from Juglans sp. in California (17). The same taxon was also recovered from diseased leaves and stems of rhododendron plants during the statewide survey of nurseries and garden centers for $P$. ramorum, and from disease samples in the past 4 years (C. Hong, unpublished data). This taxon is part of the well-known species complex $P$. citricola. Host plants currently listed under $P$. citricola belong to 75 genera in 38 families (8). The scope and number of those plants is not known, besides species of Rhododendron and Juglans and the six test plants identified in the present study, which may also host the Cil I taxon. Sorting out this species complex is currently underway in our lab in cooperation with Dr. Gallegly of West Virginia University, Morgantown, which would be the first 
and essential step to approach this question.

The health risk posed by the Cil I taxon is likely to increase over time, particularly in container production nurseries. After it was incorporated into the potting mix, 11 of the 12 species assessed in the present study declined over time, but the Cil I isolate established itself and started to grow in the absence of test plants. This growth was enhanced by the presence of host plants (Fig. 3). These results corroborate previous observations that potting mixes generally are suppressive for many Phytophthora species, but $P$. citricola is an exception $(22,25)$. We cannot be certain whether the $P$. citricola isolates used in those studies belong to the Cil I taxon. But we do know that this new taxon and $P$. citricola in general are homothallic and always produce numerous oospores even in purified cultures. The abundance of thick-walled sexual structures is likely to have given these species an edge over their relatives in endurance and growth under unfavorable environments. The Cil I taxon likely will prevail among the Phytophthora species present in ornamental nurseries and become a growing problem. This taxon and P. citricola as a whole should be monitored closely in disease and fungicide resistance development in container production nurseries.

\section{ACKNOWLEDGMENTS}

This study was supported in part by Virginia Nursery and Landscape Association, Virginia Agricultural Council, and the USDA/CSREES/Risk Avoidance and Mitigation Program (Agreement \#:2005-51101-02337).

\section{LITERATURE CITED}

1. Aragaki, M., and Uchida, J. Y. 2001. Morphological distinctions between Phytophthora capsici and $P$. tropicalis sp. nov. Mycologia 93:137-145.

2. Baker, K. F., and Linderman, R. G. 1979. Unique features of the pathology of ornamental plants. Annu. Rev. Phytopathol. 17:253277.

3. Bush, E. A. 2002. Characterization of Phy- tophthora species in recycled irrigation water at a container nursery in southwestern Virginia. M.S. thesis. Virginia Polytechnic Institute and State University, Blacksburg, VA.

4. Cooke, D. E. L., Drenth, A., Duncan, J. M., Wagels, G., and Brasier, C. M. 2000. A molecular phylogeny of Phytophthora and related oomycetes. Fungal Genet. Biol. 30:17-32.

5. Daughtrey, M. L., and Benson, D. M. 2005. Principles of plant health management for ornamental plants. Annu. Rev. Phytopathol. 43:141-169.

6. Erwin, D. C., and Ribeiro, O. K. 1996. Phytophthora Diseases Worldwide. American Phytopathological Society, St. Paul, MN.

7. Farr, D. F., Bills, G. F., Chamuris, G. P., and Rossman, A. Y. 1989. Fungi on Plants and Plant Products in the United States. American Phytopathological Society, St. Paul, MN.

8. Farr, D. F., Rossman, A. Y., Palm, M. E., and McCray, E. B. 2008. Fungal Databases at http://nt.ars-grin.gov/fungaldatabases/. Systematic Mycology and Microbiology Laboratory, U.S. Dep. Agric. Agric. Res. Serv.

9. Ferguson, A. J., and Jeffers, S. N. 1999. Detecting multiple species of Phytophthora in container mixes from ornamental crop nurseries. Plant Dis. 83:1129-1136.

10. Gallegly, M. E., and Hong, C. X. 2008. Phytophthora: Identifying Species with Morphology and DNA Fingerprints. American Phytopathological Society, St. Paul, MN. In press.

11. Hansen, E. M., Parke, J. L., and Sutton, W. 2005. Susceptibility of Oregon forest trees and shrubs to Phytophthora ramorum: A comparison of artificial inoculation and natural infection. Plant Dis. 89:63-70.

12. Hong, C. X., Gallegly, M. E., Richardons, P. A., Kong, P., Moorman, G. W., Lea-Cox, J. D., and Ross, D. S. Phytophthora irrigata and Phytophthora hydropathica, two new species from irrigation water at ornamental plant nurseries. (Abstr.) Phytopathology In press.

13. Hong, C. X., and Moorman, G. W. 2005. Plant pathogens in irrigation water: Challenges and opportunities. Crit. Rev. Plant Sci. 24:189-208.

14. Hong, C. X., Richardson, P. A., and Kong, P. 2002. Comparison of membrane filters as a tool for isolating pythiaceous species from irrigation water. Phytopathology 92:610-616.

15. Hong, C. X., Richardson, P. A., Kong, P., Jeffers, S. N., and Oak, S. W. 2006. Phytophthora tropicalis isolated from diseased leaves of Pieris japonica and Rhododendron catawbiense and found in irrigation water and soil in Virginia. Plant Dis. 90:525.

16. Kong, P., Hong, C. X., and Richardson, P. A. 2003. Rapid detection of Phytophthora cinna- momi using PCR with primers derived from the $L P V$ putative storage protein genes. Plant Pathol. 52:681-693.

17. Kong, P., Hong, C. X., Richardson, P. A., and Gallegly, M. E. 2003. Single-strandconformation polymorphism of ribosomal DNA for rapid species differentiation in genus Phytophthora. Fungal Genet. Biol. 39:238249.

18. Kong, P., Hong, C. X., Tooley, P. W., Ivors, K. Garbelotto, M., and Richardson, P. A. 2004. Rapid identification of Phytophthora ramorum using PCR-SSCP analysis of ribosomal DNA ITS-1. Lett. Appl. Microbiol. 38:433-439.

19. Kroon, L., Bakker, F. T., van den Bosch, G. B. M., Bonants, P. J. M., and Flier, W. G. 2004. Phylogenetic analysis of Phytophthora species based on mitochondrial and nuclear DNA sequences. Fungal Genet. Biol. 41:766-782.

20. Linderman, R. G., Davis, E. A., and Marlow, J. L. 2006. Response of selected nursery crop plants to inoculation with isolates of Phytophthora ramorum and other Phytophthora species. Horttechnology 16:216-224.

21. Martin, F. N., and Tooley, P. W. 2004. Identification of Phytophthora isolates to species level using restriction fragment length polymorphism analysis of a polymerase chain reactionamplified region of mitochondrial DNA. Phytopathology 94:983-991.

22. Pokorny, F. A., and Dunavent, M. G. 1995 Phytophthora suppressed by pine bark extracts. Proc. Sou. Nur. Res. Conf. 40:235236.

23. Rizzo, D. M., Garbelotto, M., and Hansen, E. A. 2005. Phytophthora ramorum: Integrative research and management of an emerging pathogen in California and Oregon forests. Annu. Rev. Phytopathol. 43:309-335.

24. Roiger, D. J., and Jeffers, S. N. 1991. Evaluation of Trichoderma spp. for biological control of Phytophthora crown and root rot of apple seedlings. Phytopathology 81:910-917.

25. Spencer, S., and Benson, D. M. 1982. Pine bark, hardwood bark compost, and peat amendment effects on development of Phy tophthora spp. and lupine root rot. Phytopathology 72:346-351.

26. Tooley, P. W., and Kyde, K. L. 2007. Susceptibility of some Eastern forest species to Phytophthora ramorum. Plant Dis. 91:435-438.

27. Tooley, P. W., Kyde, K. L., and Englander, L. 2004. Susceptibility of selected ericaceous ornamental host species to Phytophthora ramorum. Plant Dis. 88:993-999.

28. Tucker, C. M. 1931. Taxonomy of the genus Phytophthora de Bary. University of Missouri Agric. Exp. Stn. Res. Bull. 153. 